\title{
PELAKSANAAN PIJAT DIARE PADA BAYI DIARE DI PMB MURTINAWITA PEKANBARU TAHUN 2020
}

\author{
Een Husanah , Salnis Midian Haria \\ STIKes Hang Tuah Pekanbaru
}

\begin{abstract}
Diarrhea is the frequency of excreting more often ( 3 more than times a day) in one day( 24, ) hours and forms of fecal matter more liquid than usual.Diarrhea remains a problem in the main health. in the worldThe republic of indonesia health departeman stated that a toddler diarrhea is second in indonesia after pneumonia.tujuan devotion to this community to overcome the problem of diarrhea in infants who had diarrhea.Methods used in the devotion is, counseling question and answer about the material presented and the implementation of massage. in infantsThe results show that event can solve the problems of diarrhea in infants and she can practice massage. diarrheaWas expected to diarrhea in infants can be done massage diarrhea thus midwife practices independent can update the especially about. massage
\end{abstract}

Keywords: Infants, Diarhhea Massage

\begin{abstract}
ABSTRAK
Diare adalah buang air besar dengan frekuensi lebih sering (lebih dari 3 kali sehari) dalam satu hari (24 jam), dan bentuk tinja lebih cair dari biasanya. Diare masih merupakan masalah kesehatan utama pada anak di dunia. Departeman Kesehatan Republik Indonesia menyatakan bahwa diare merupakan pembunuh balita kedua di Indonesia setelah pneumonia.Tujuan pengabdian kepada masyarakat ini mengatasi masalah diare pada bayi yang mengalami diare. Metode yang digunakan dalam kegiatan pengabdian ini adalah penyuluhan, tanya jawab tentang materi yang disampaikan serta pelaksanaan pijat pada bayi. Hasil menunjukkan bahwa kegiatan yang dilaksanakan dapat mengatasi masalah diare pada bayi dan ibu dapat mempraktikkan pijat diare. Diharapkan untuk asuhan pada bayi diare dapat dilakukan pijat diare sehingga bidan praktik mandiri dapat mengupdate ilmu terutama tentang pijat.
\end{abstract}

Kata Kunci: Bayi, Pijat Diare

\section{PENDAHULUAN}

Menurut Departemen Kesehatan (2009), masa bayi adalah masa keemasan sekaligus masa kritis perkembangan seseorang. Dikatakan masa kritis karena pada masa ini bayi sangat peka terhadap lingkungan dan dikatakan masa keemasan karena masa bayi berlangsung sangat singkat dan tidak dapat diulang kembali. Bayi merupakan individu yang berusia $0-12$ bulan yang ditandai dengan pertumbuhan dan perkembangan yang cepat disertai dengan perubahan dalam 
kebutuhan zat gizi (Masyarakat et al., 2017).

Dalam masa perkembangannya, bayi mengalami beberapa masalah kesehatan salah satunya masalah diare. Menurut World Health Organization (WHO), diare adalah buang air besar dengan frekuensi lebih sering (lebih dari 3 kali sehari), dan bentuk tinja lebih cair dari biasanya. Dengan demikian, bayi dikatakan terkena diare jika sudah lebih dari 3 kali buang air besar, sedangkan neonatus dikatakan diare jika sudah lebih dari 4 kali buang air besar (Putra, 2012).

Penyakit diare di Indonesia masih menjadi salah satu masalah kesehatan masyarakat yang utama. Hal ini disebabkan karena masih tingginya angka kesakitan dan kematian terutama pada balita. Diperkirakan lebih dari 1,3 miliar serangan dan 3,2 juta kematian per tahun pada balita disebabkan oleh diare. Setiap anak mengalami episode serangan diare rata-rata 3,3 kali setiap tahun dan lebih dari $80 \%$ kematian terjadi pada anak berusia kurang dari dua tahun (Ragil \& Dyah, 2017).

Diare masih merupakan masalah kesehatan utama pada anak di dunia. Setiap tahunnya terdapat sekitar 2 milyar kasus diare di dunia dan 1,9 juta anak usia di bawah 5 tahun meninggal karena diare. Lebih dari setengah kematian pada balita yang diakibatkan oleh diare terjadi di negara berkembang seperti India, Nigeria, Afghanistan, Pakistan, dan Ethiopia. Setiap tahunnya terdapat $25,2 \%$ balita di Indonesia yang meninggal dunia karena diare (Arsurya et al., 2017).

Departeman Kesehatan Republik Indonesia menyatakan bahwa diare merupakan pembunuh balita kedua di Indonesia setelah pneumonia. Diare berkontribusi sekitar $18 \%$ dari seluruh kematian balita di dunia atau setara dengan lebih dari 5 ribu balita meninggal perhari (Arsurya et al., 2017) .

Pijat terbukti membantu dalam mengatasi beberapa kondisi anak, termasuk di dalamnya berat badan rendah, nyeri, asthma, attention deficit hyperactive disorder (ADHD), dan depresi. Pijat dapat merangsang aliran darah yang akan membawa oksigen dan nutrisi pada jaringan yang dipijat (Novianti, 2012).

Dampak positif yang diperoleh dari pijat bayi yaitu meningkatkan jumlah sel dan daya racun dari sistem imunitas, mengubah gelombang otak secara positif, memperbaiki sirkulasi darah dan pernapasan, merangsang fungsi pencernaan serta pembuangan, meningkatkan kenaikan berat badan, mengurangi depresi dan ketegangan, meningkatkan kesiagaan, membuat tidur terlelap, mengurangi rasa sakit, mengurangi kembung dan kolik, 
meningkatkan hubungan orangtua dan bayi (Roesli, 2007).

\section{METODE}

\section{Kerangka Pemecahan Masalah}

Metode yang digunakan dalam kegiatan pengabdian ini adalah penyuluhan, tanya jawab tentang materi yang disampaikan serta pelaksanaan pijat pada bayi. Materi yang disampaikan tentang masalah diare pada bayi, dan pijat diare pada bayi setelah penyampaian informasi tentang diare kemudian dilanjutkan denganpraktik pijat. Sasaran dalam kegiatan pengabian ini adalah ibu yang mempunyai bayi di PMB Murtinawita Pekanbaru. Dalam pengabdian ini juga dilakukan evaluasi, input, proses dan output.

\section{Rancangan Evaluasi}

Evaluasi adalah penilaian terhadap pemahaman materi yang telah disampaikan kepada ibu yang mempunyai bayi. Evaluasi dilaksanakan dalam bentuk mengulas kembali materi melalui proses tanya jawab.

Adapun indikator pencapaian dari hasil evaluasi yaitu;

1. Ibu bayi memahami apa yang dijelaskan oleh penyuluh;

2. Ibu bayi aktif dalam kegiatan tanya jawab.
3. Ibu bayi dapat melakukan pijat diare pada bayi

\section{Metode Kegiatan}

Kegiatan pengabdian dilakukan dengan cara penyuluhan dengan tema pijat diare pada bayi. Metode yang dilakukan dengan memberikan ceramah langsung dan leafleat berisi materi dan gambar yang menarik serta tanya jawab seputar diare pada bayi serta praktik pijat diare pada bayi.

\section{HASIL}

Kegiatan yang dilakukan dalam penyuluhan ini dilaksanakan dalam beberapa tahap yang diawali dengan penyampaian materi terlebih dahulu, kemudian setelah diberikan materi melakukan sesi tanya jawab serta diskusi dan dilanjutkan dengan praktik pijat diare.

Kegiatan penyuluhan ini dilaksanakan pada hari Sabtu, tanggal 22 Agustus 2020 bertempat di BPM Murtinawita Pekanbaru. Kegiatan ini memberikan hasil sebagai berikut :.

1. Ibu balita mengerti tentang penyakit diare meliputi definisi penyebab, akibat, cara mencegah dan mengobati diare.

2. Ibu dapat melakukan pijat diare pada bayi 


\section{PEMBAHASAN}

Ibu balita Sebagian besar mengetahui penyakit diare hanya diobati dengan terapi farmakologi saja seperti obat obatan. Ibu balita belum pernah mengetahui terapi pijat dapat mengatasi penyakit diare pada bayi.

Maka dilakukan kegiatan penyuluhan mengenai pelaksanaan pijat diare. rangkaian acara berjalan dengan baik dan sesuai rencana. Hal ini terbukti antusiasme ibu balita saat mengikuti jalannya kegiatan dan aktifnya ibu balita untuk bertanya tentang masalah-masalah kesehatan bayi yang berkaitan dengan pijat hal ini dikarenakan informasi baru yang mereka dapat tentang pijat diare pada bayi.

\section{KESIMPULAN}

Penyakit diare pada bayi tidak boleh disepelakan perlu ditangani dengan baik selain terapi dengan obat obatan sekarang diare dapat diatasi dengan tenik pijat yaitu pijat diare. Selain dapat mengatasi masalah diare pijat pada bayi juga memberikan manfaat bagi ibu dan bayi Bayi dapat menjadi lebih rileks dan tenang serta dapat menjalin hubungan kasih sayang antara ibu dan anak. Jika pijat dilakukan oleh ibu bayi. Berdasarkan kegiatan yang telah dilaksanakan, maka dapat disimpulkan beberapa hal yaitu daya serap ibu bayi terhadap materi kegiatan cukup baik, sikap antusias dan rasa ingin tahu ibu bayi sangat baik, dan terjalinnya keakraban dan suasanan kekeluargaan dengan para pemberi materi nara sumber).

\section{SARAN}

Memberikan

pendidikan kesehatan kepada ibu bayi bahwa untuk mengatasi diare pada bayi tidak hanya dengan mengkonsumsi obat obatan saja tapi teknik pijat diare juga dapat membantu mengatasi penyakit diare pada bayi. Yang dapat dilakukanoleh ibu yang mempunyai bayi.

\section{DAFTAR PUSTAKA}

Arsurya, Y., Rini, E. A., \& Abdiana, A. (2017). Hubungan Tingkat Pengetahuan Ibu tentang Penanganan Diare dengan Kejadian Diare pada Balita di Kelurahan Korong Gadang Kecamatan Kuranji Kota Padang. Jurnal Kesehatan $\begin{array}{lll}\text { Andalas, } & 6(2), & \end{array}$ https://doi.org/10.25077/jka.v6.i2.p4 52-456.2017

Masyarakat, P., Tayangan, T., \& Kopi, S. (2017). Universitas Sumatera Utara - Campak. x, 84-90. 
Novianti, S. W. (2012). Pengaruh Terapi

Pijat Bayi Dalam Penurunan Frekuensi $B A B$ dan Tingkat Dehidrasi Pada Anak Usia 0- 2 Tahun Dengan Diare di RSUD Cibarat Cimahi. https://doi.org/10.1017/CBO9781107 415324.004

Putra, S. R. (2012). Asuhan Neonatus Bayi dan Balita untuk Keperawatan dan Kebidanan. Jogjakarta : DMEDIKA.

Roesli, U. (2016). Pedoman Pijat Bayi. Jakarta : Trubus Agriwidya
Ragil, D. W., \& Dyah, Y. P. (2017). Jurnal of Health Education Hubungan Antara Pengetahuan Dan Kebiasaan Mencuci Tangan Pengasuh Dengan Kejadian Diare Pada Balita Info Artikel. Jhe, 2(1), 39-46.

http://journal.unnes.ac.id/sju/index.p hp/jhealthedu/

Sasmitawati, E. (2010). Jangan Sepelekan DIARE. Jakarta Selatan : PT Sunda Kelapa Pustaka.

Simanungkalit, H. M. (2019). Baby Massage terhadap Frekuensi Buang Air Besar pada Balita dengan Diare. Jurnal Berkala Kesehatan, 53-59. 